\title{
Pellet Quality of Corn-Based DDGS
}

\author{
Mingjun $\mathrm{Ma}^{1}$ \& Kurt A. Rosentrater ${ }^{1}$ \\ ${ }^{1}$ Iowa State University, USA \\ Correspondence: Kurt A. Rosentrater, Iowa State University, USA. E-mail: karosent@iastate.edu
}

Received: March 24, 2021

Accepted: April 17, $2021 \quad$ Online Published: April 20, 2021

doi:10.5539/jfr.v10n3p25

URL: https://doi.org/10.5539/jfr.v10n3p25

\begin{abstract}
The rapid growth of corn-based dry grind ethanol plants over the past decade in the US has resulted in a great increase in production of the coproduct DDGS (distillers dried grains with solubles). Since some physical properties like low bulk density and poor flowability can impact the market potential of DDGS, pelleting of DDGS can be one of the easiest ways to improve this situation. Pellet quality is the focus of this project. The pelleting process was conducted with three initial DDGS moisture contents and two different dies; a total of six runs were completed to produce DDGS pellets. The physical qualities of pelleted DDGS were determined by measuring durability, bulk density, angle of repose, and color of the pellets. The results showed that the durability ranged from $42 \%$ to $89 \%$, the highest pellet durability occurred when the moisture content was $20 \%$ $\mathrm{db}$ and the die diameter was $1 / 8 \mathrm{in}$. The bulk density increased when the DDGS moisture content decreased, and the highest bulk density was observed when the moisture content was $10 \% \mathrm{db}$ and the die diameter was $1 / 8$ in.
\end{abstract}

Keywords: DDGS, distillers grains, pelleting, pellet quality, physical properties

\section{Introduction}

The cost of non-renewable fossil fuels has significantly fluctuated in last several decades, due to the potential decline in overall fossil fuel supply in coming years, as well as a variety of other international factors. There are two solutions to this problem: using alternative energy sources and becoming more independent on energy sources (RFA, 2008). Ethanol, a renewable source of energy, is an alternative to fossil fuels. Various biomass materials can be used to produce biofuels. Currently, corn is the primary material utilized to produce biofuels in U.S. The corn ethanol industry has been well developed and the cost of using corn is much lower compared to other biomass sources. Therefore, the fuel ethanol industry has grown rapidly in recent years. For example, in the past few years, ethanol has been established at 10 percent of the U.S. gasoline supply (RFA, 2014).

Currently, dry grind ethanol production processing dominates the ethanol manufacturing industry. Like many other industrial processes, dry grind processing also has co-products, which are carbon dioxide and non-fermentable residuals. The non-fermentable corn kernel components such as fiber, proteins, and lipids are usually further processed and converted into DDGS (distillers dried grains with solubles), and to a lesser degree as DDG (distillers dried grains), DWG (distiller wet grains), and CDS (condensed distillers solubles) (Liu and Rosentrater, 2011). DDGS is normally dried to around $10 \%$ moisture content, to extend the storage life.

Although distillers grains can be utilized as high value animal feed ingredients, there are different kinds of challenges when utilizing DDGS. Low bulk density and poor flowability have been two key challenges when handling DDGS (Rosentrater, 2006a, and Rosentrater, 2006b). Once a truck or train reaches destination, DDGS can be hard to discharge due to the particles locking together. Thus, low flowability forces strenuous manual unloading processes, which create extra labor costs for ethanol manufacturers, livestock producers, etc. Another transportation problem of DDGS is the limited loading capacity of rail cars. DDGS is often filled to the volumetric capacity of railcars or trucks during shipping, but usually not at the maximum allowable weight, due to the low bulk density of this granular material. Thus, this wasted capacity causes additional potential economic losses to the ethanol manufacturers (Rosentrater and Kongar, 2009). There is a way to increase the bulk density and flowability of DDGS: utilizing pelletizing equipment. Pelleting is a manufacturing process which compresses materials into the shape of pellets, and can improve the value of granular materials (Rosentrater, 2005). Rosentrater (2007) has indicated that it is achievable to use conventional feed milling equipment to pelletize DDGS.

Previous research studies have discussed the process variables that affect the physical qualities of resultant 
pellets, and the impact of pelleting on the logistics of DDGS shipping. However, there is still very limited work regarding analysis of the physical qualities of DDGS pellets by using 100\% corn-based DDGS. The aim of this research was to study the resultant pellet qualities of corn-based DDGS. The results of this research may be the reference for a large-scale facility producing DDGS pellets, and may help the animal feed industry improve the value of DDGS while reducing the cost of utilizing DDGS as animal feed ingredients.

\section{Materials and Methods}

\subsection{Materials and Equipment}

The DDGS was collected from a local dry grind ethanol plant (Lincolnway Energy, LLC, Nevada, IA). Two bins of DDGS were stored at room temperature until use. The pelleting process was completed using a $1.5 \mathrm{~kW}$ pilot-scale pellet mill (CPM model CL-2, CPM Corp., Crawfordsville, IN). The pellet mill consisted of an ingredient hopper to hold the DDGS, a vibratory feeder to adjust the feeding rate of the DDGS that goes into the screw feeder, and then the screw feeder pushed the DDGS into the mill. After the pelleting process, the DDGS pellets were discharged from the bottom. The pellet mill was also equipped with a panel to control the mill and change the ingredient feeding rate (Figure 1).

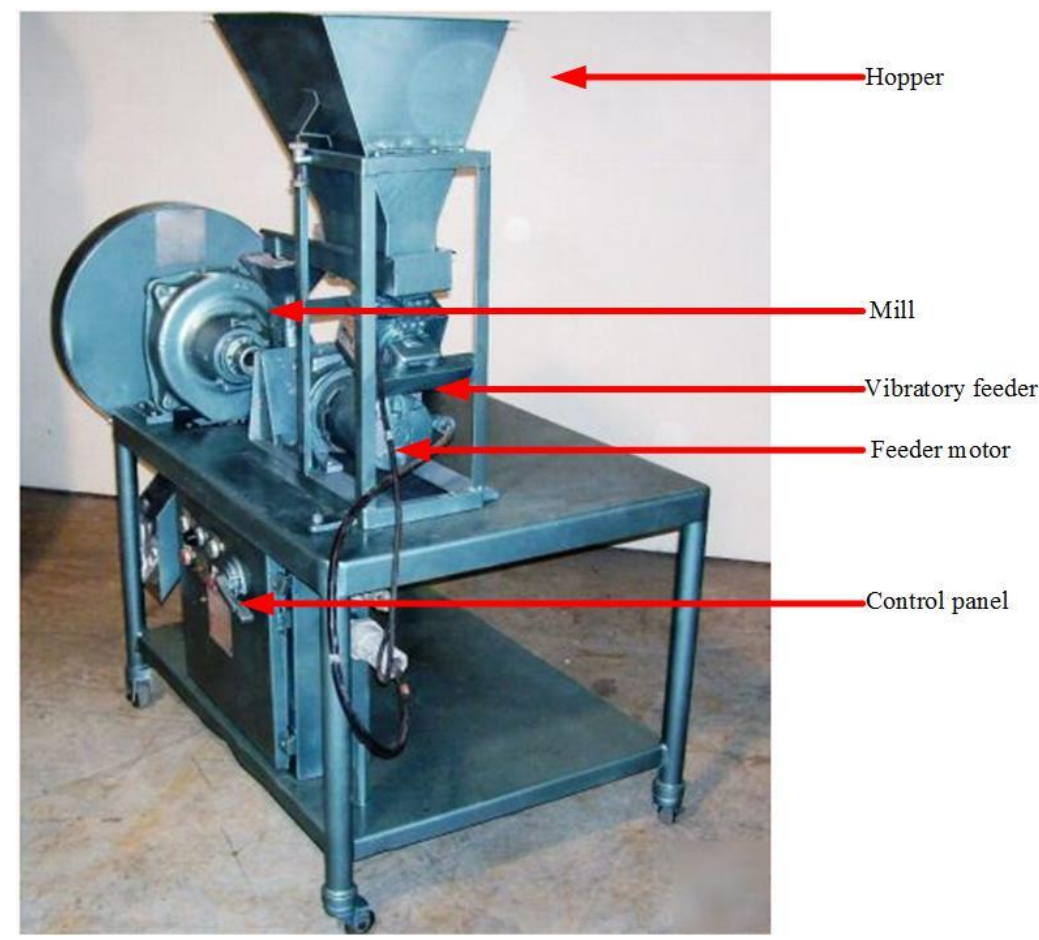

Figure 1. CPM CL-2 pelleting mill

\subsection{Experimental Design}

Table 1 shows the experimental design for this study. Two dies diameters of $1 / 8$ in with the $\mathrm{L} / \mathrm{D}$ ratio of 8 , and a diameter of 3/16 in with the L/D ratio of 8 , were used for this study (Figure 2). For each die, the DDGS was preconditioned to three different moisture levels: $10 \%$ 15\% and 20\% (wet basis), respectively. The table also shows the rate of throughput used for each run.

Table 1. Pelleting processing conditions used in the study

\begin{tabular}{llllll}
\hline & Die Size & & & DDGS & \\
\hline Run & Diameter (in) & Length (in) & L/D & Moisture (db\%) & Throughput (lb/hr) \\
\hline 1 & & & & 10 & \\
2 & $1 / 8$ & 1 & 8 & 15 & 37.5 \\
3 & & & & 20 & \\
4 & & \multirow{2}{*}{$11 / 2$} & 8 & 10 & 52 \\
5 & $3 / 16$ & & & 20 & \\
6 & & & & & \\
\hline
\end{tabular}




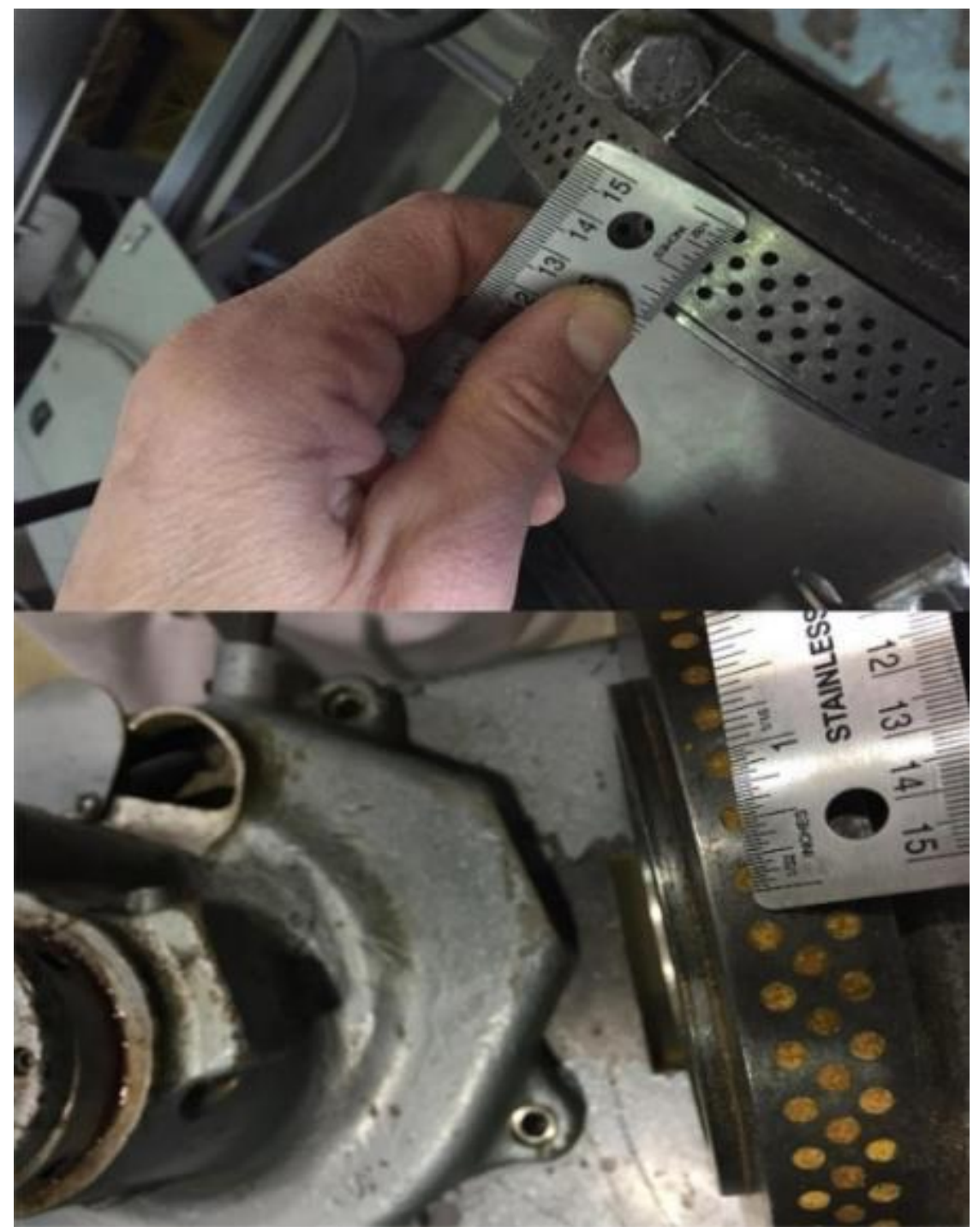

Figure 2. Different dies used in the pelleting process (1/8 in above; $3 / 16$ in below)

There were a total of six runs for the combinations of die sizes and DDGS moisture contents in this study. For each run, two replications of the pelleting process were done to produce pellet samples. (thus $\mathrm{n}=2$ for each experimental treatment). The pelleting throughput represents the production rate of converting raw DDGS to DDGS pellets. The throughput rate was adjusted based on the die size. The feeding rate of the ingredients was controlled by adjusting the vibratory feeder on the control panel.

\subsection{Moisture Content}

The DDGS and DDGS pellet moisture contents were measured based on the NFTA (National Forage Testing Association) 2.2.2.5 method (Shreve et al., 2006)., using $3 \mathrm{~g}$ of DDGS or DDGS pellet sample, they were dried at $105{ }^{\circ} \mathrm{C}$ for $3 \mathrm{~h}$ in a laboratory oven. For each duplicate run, the sample moisture content was measured three times, and both means and standard deviations were reported.

\subsection{DDGS Moisture Content Adjustments}

The DDGS moisture content was adjusted to three levels: $10 \%, 15 \%$, and 20\%. To adjust the DDGS moisture content, the sample was placed in a bucket, and the pre-calculated quantity of water was added and mixed with the DDGS. The was added to DDGS samples directly by using a sprayer and then mixed using an electric mixer.

\subsection{Bulk Density}

The DDGS and DDGS pellet samples were allowed to flow freely into a one-liter cup. Then a striking stick was 
used to brushed off the excesses sample with gentle zig-zag strokes. The bulk density of DDGS or DDGS pellets was then calculated by dividing the DDGS or pellet mass by the volume of the container. The measured was repeated three times for each sample; means and standard deviations were calculated and reported.

\subsection{Angle of Repose}

The angle of repose (AoR) is the steepest angle of inclination of the free surface to the horizontal of a granular material heap. It is one of the flow properties that directly indicates the potential flowability (Carr, 1965). Based on Woodcock and Mason (1987) a material angle of repose ranging from $30^{\circ}$ to $38^{\circ}$ is considered free flowing, while an angle of repose ranging from $38^{\circ}$ to $45^{\circ}$ is considered fair flow. If the material angle of repose is between $45^{\circ}$ to $55^{\circ}$ the material is considered a cohesive material.

\subsection{Pellet Durability}

Pellet durability was measured regarding ASAE S269.5 (ASAE, 2012). A pellet durability tester (Seedburo Equipment Co., Des Plaines, IL) was used for this measurement. Before the durability test of the DDGS pellets, the pellets were first sieved and then randomly sampled; $500 \mathrm{~g}$ of pellets were selected for each test. The sample was tumbled $10 \mathrm{~min}$ inside the durability tester; after tumbling the sample was sieved to separate the remaining pellets from the resulting fines. The pellet durability was cthen alculated by dividing the mass of remaining pellets by the initial mass of the pellet sample. Three tests were done for each experimental run; the means and standard deviations were also calculated and reported in the results section.

\subsection{Color}

A Minolta Chromameter (Chromameter CR-410, Konica Minolta Sensing Europe B.V.) was used to measure the color of DDGS and DDGS pellets. The color was determined via three parameters, including $L^{*}, a^{*}$ and $b^{*}$, in which $L^{*}$ represents the lightness level, $a^{*}$ represents the green - red level, and $b^{*}$ represents blue - yellow level. For each pellet sample, three replications were done to measure the color means and standard deviations were calculated and reported in the results section.

\section{Results and Discussion}

Table 2 and Table 3 report the moisture content results and the associated statistical analyses. For both runs 1-3 and runs 4-6, the moisture content of DDGS pellets varied from $10 \%$ to $20 \%$ and followed the initial DDGS moisture level. It was determined that the die size had no significant influence on the final DDGS pellet moisture content, while the initial DDGS moisture level had a significant effect on the final DDGS pellet moisture content. This also resulted in the die size and moisture level together having a combined significant effect on final pellet moisture content.

Table 2. Moisture content for DDGS and DDGS pellets*

\begin{tabular}{llllllll}
\hline \multicolumn{7}{c}{ Pellet Moisture Content(\%) } \\
\hline Run & $\begin{array}{l}\text { Die } \\
\text { (in) }\end{array}$ & $\begin{array}{l}\text { DDGS Moisture } \\
\text { level(\%) }\end{array}$ & Replication 1 & Replication 2 & Replication 3 & Mean & $\begin{array}{l}\text { Standard } \\
\text { deviation }\end{array}$ \\
\hline DDGS & 10 & 10.4 & 10.5 & 10.7 & $10.5 \mathrm{a}$ & 0.15 \\
1 & & 10 & 10.6 & 10.3 & 10.3 & $10.4 \mathrm{a}$ & 0.17 \\
2 & $1 / 8$ & 15 & 14.3 & 14.9 & 14.6 & $14.6 \mathrm{~b}$ & 0.30 \\
3 & & 20 & 19.7 & 20.3 & 20.5 & $20.1 \mathrm{c}$ & 0.41 \\
4 & & 10 & 10.9 & 10.4 & 10.6 & $10.6 \mathrm{a}$ & 0.25 \\
5 & $3 / 16$ & 15 & 14.7 & 15.5 & 15.3 & $15.1 \mathrm{~b}$ & 0.41 \\
6 & & 20 & 19.8 & 21.2 & 20.6 & $20.5 \mathrm{c}$ & 0.70 \\
\hline
\end{tabular}

*Different letters after means in each level of the moisture content indicates significant difference at $\alpha=0.05$

Table 3. ANOVA for moisture content of DDGS pellets*

\begin{tabular}{llll}
\hline Factor & $\mathrm{DF}^{*}$ & $\mathrm{~F}$ value & $\mathrm{P}_{\mathrm{r}}>\mathrm{F}$ \\
\hline Die Size & 1 & 0.037 & 0.8497 \\
Moisture & 2 & 777.01 & $<.0001$ \\
Die size x Moisture & 5 & 342.48 & $<.0001$ \\
\hline
\end{tabular}

*Degrees of freedom 
Regarding pellet bulk density, for runs $1-3$ the bulk density varied from $510.3 \mathrm{~kg} / \mathrm{m}^{3}$ to $571.4 \mathrm{~kg} / \mathrm{m}^{3}$, while for runs $4-6$ bulk density ranged from $482.1 \mathrm{~kg} / \mathrm{m}^{3}$ to $490.2 \mathrm{~kg} / \mathrm{m}^{3}$. All the pellet bulk densities were significantly increased compared to the raw DDGS bulk density, which was $465 \mathrm{~kg} / \mathrm{m}^{3}$. The die size and the interaction between die size and DDGS moisture level had a significant effect on bulk density, since the p-values were smaller than 0.0001 (Table 5). For each die, the pellet bulk density was decreased when the initial DDGS moisture content increased. Tumuluru et al. (2010) also observed that for pilot scale DDGS pelleting, the DDGS bulk density was increased after the pelleting process. The bulk density results were also very similar to Fasina and Sokhansanj (1993), where they found that for each die used, the pellet bulk density was decreased when the pellet moisture content increased.

Table 4. Bulk density of DDGS pellets*

\begin{tabular}{llllllll}
\hline \multicolumn{7}{l}{ Pellet Bulk Density $\left(\mathrm{kg} / \mathrm{m}^{3}\right)$} \\
\hline Run & $\begin{array}{l}\text { Die } \\
\text { (in) }\end{array}$ & $\begin{array}{l}\text { DDGS Moisture } \\
\text { level(\%) }\end{array}$ & Replication 1 & Replication 2 & Replication 3 & Mean & $\begin{array}{l}\text { Standard } \\
\text { deviation }\end{array}$ \\
\hline DDGS & 10 & 10 & 465.2 & 467.1 & 465.5 & $465.9 \mathrm{a}$ & 1.02 \\
1 & & 10 & 572.4 & 571.8 & 569.9 & $571.4 \mathrm{~b}$ & 1.3 \\
2 & $1 / 8$ & 15 & 527.3 & 531.7 & 530.2 & $529.7 \mathrm{c}$ & 2.2 \\
3 & & 20 & 512.4 & 508.1 & 510.3 & $510.3 \mathrm{~d}$ & 2.2 \\
4 & & 10 & 488.7 & 490.5 & 491.3 & $490.2 \mathrm{e}$ & 1.3 \\
5 & $3 / 16$ & 15 & 485.5 & 484.9 & 484.7 & $485.0 \mathrm{f}$ & 2.0 \\
6 & & 20 & 480.5 & 482.3 & 483.5 & $482.1 \mathrm{~g}$ & 1.5 \\
\hline
\end{tabular}

* Different letters after means in each level of the bulk density indicates significant difference at $\alpha=0.05$

Table 5. ANOVA for bulk density of DDGS pellets*

\begin{tabular}{llll}
\hline Factor & $\mathrm{DF}^{*}$ & $\mathrm{~F}$ value & $\mathrm{P}_{\mathrm{r}}>\mathrm{F}$ \\
\hline Die Size & 1 & 31.77 & $<.0001$ \\
Moisture & 2 & 1.9863 & 0.1717 \\
Die size x Moisture & 5 & 1088.57 & $<.0001$ \\
\hline
\end{tabular}

*Degrees of freedom

The pellet durability results are reported in Tables 6 and Table 7. For runs 1-3 the durability of pellets varied from $73.2 \%$ to $89.27 \%$; for runs $4-6$ the durability of pellets ranged from $42.5 \%$ to $60.5 \%$. The analysis shows that all the pellet durability data were significantly different from each other. Die size and the interactions between die size and DDGS moisture level have a significant effect on the DDGS pellet durability value. Comparing the results from runs 1-3 with run s1-6, we can observe that even though these two dies have same $\mathrm{L} / \mathrm{D}$ ratio, the die with smaller die diameter resulted in higher durability and bulk density values. The reasons for this difference may be due to different pressure level generated during the pelleting process, as well as frictional heating and binding.

Table 6. Durability of DDGS pellets*

\begin{tabular}{llllllll}
\hline \multicolumn{2}{l}{ Pellet Durability (\%) } & & & & & \\
\hline Run & $\begin{array}{l}\text { Die } \\
\text { (in) }\end{array}$ & $\begin{array}{l}\text { DDGS Moisture } \\
\text { level(\%) }\end{array}$ & Replication 1 & Replication 2 & Replication 3 & Mean & $\begin{array}{l}\text { Standard } \\
\text { deviation }\end{array}$ \\
\hline 1 & & 10 & 72.6 & 72.9 & 74.1 & $73.2 \mathrm{a}$ & 0.8 \\
2 & $1 / 8$ & 15 & 80.6 & 80.3 & 78.4 & $79.8 \mathrm{~b}$ & 1.2 \\
3 & & 20 & 89.4 & 89.2 & 89.2 & $89.3 \mathrm{c}$ & 0.1 \\
4 & & 10 & 42.6 & 42.4 & 42.5 & $42.5 \mathrm{~d}$ & 0.1 \\
5 & $3 / 16$ & 15 & 48.6 & 46.2 & 57.6 & $57.5 \mathrm{e}$ & 1.2 \\
6 & & 20 & 60.8 & 60.2 & 60.5 & $60.5 \mathrm{f}$ & 0.3 \\
\hline
\end{tabular}

* Different letters after means in each level of the durability results indicates significant difference at $\alpha=0.05$ 
Table 7. ANOVA for durability of DDGS pellets*

\begin{tabular}{lllll}
\hline Factor & $\mathrm{DF}^{*}$ & $\mathrm{~F}$ value & $\mathrm{P}_{\mathrm{r}}>\mathrm{F}$ \\
\hline Die Size & 1 & 55.95 & $<.0001$ \\
Moisture & 2 & 1.96 & 0.1753 \\
Die size x Moisture & 5 & 1374.11 & $<.0001$ \\
\hline
\end{tabular}

*Degrees of freedom

From Table 8, the values of angle of repose for runs 1-3 varied from $36.4^{\circ}$ to $43.8^{\circ}$, while for runs $4-6$ the angle of repose varied from $37.4^{\circ}$ to $44.8^{\circ}$, which were very similar to runs 1-3. From these results, it can be observed that after the pelleting process the angle of repose value was smaller than the initial DDGS angle of repose (which was $47.0^{\circ}$ ) This means that the pelleting process could increase the material flowability substantially. According to Woodcock and Mason (1987), all the DDGS pellets could thus be classified as "fair flow" or even "free flow". The pellet angle of repose increased as the DDGS moisture level increased for the same die - which was expected as moisture increases lead to decreased flowability. The results were similar to Fasina and Sokhansanj (1993) where the alfalfa pellet angle of repose also increased as the alfalfa pellet moisture content level increased for the same pellet size. Table 9 shows the statistical analyses for the angle of repose results, the moisture content and the interaction of moisture content with die size had a significant effect on pellet angle of repose results.

Table 8. Angle of repose of DDGS pellets*

\begin{tabular}{llllllll}
\hline \multicolumn{2}{l}{ Pellet Angle of Repose $\left(^{(}\right)$} & & & & & \\
\hline Run & $\begin{array}{l}\text { Die } \\
\text { (in) }\end{array}$ & $\begin{array}{l}\text { DDGS Moisture } \\
\text { level }(\%)\end{array}$ & Replication 1 & Replication 2 & Replication 3 & Mean & $\begin{array}{l}\text { Standard } \\
\text { deviation }\end{array}$ \\
\hline DDGS & 10 & 47.6 & 46.9 & 46.7 & $47.0 \mathrm{a}$ & 0.47 \\
1 & & 10 & 35.9 & 36.5 & 36.9 & $36.4 \mathrm{~b}$ & 0.5 \\
2 & $1 / 8$ & 15 & 39.5 & 38.8 & 38.7 & $39.0 \mathrm{c}$ & 0.4 \\
3 & & 20 & 43.3 & 43.9 & 44.2 & $43.8 \mathrm{~d}$ & 0.5 \\
4 & 10 & 37.6 & 37.9 & 36.7 & $37.4 \mathrm{e}$ & 0.6 \\
5 & $3 / 16$ & 15 & 40.9 & 39.9 & 40.5 & $40.4 \mathrm{f}$ & 0.5 \\
6 & 20 & 44.9 & 44.7 & 44.8 & $44.8 \mathrm{~g}$ & 0.6 \\
\hline
\end{tabular}

* Different letters after means in each level of the angle of repose indicates significant difference at $\alpha=0.05$

Table 9. ANOVA for angle of repose of DDGS pellets*

*Degrees of freedom

\begin{tabular}{llll}
\hline Factor & $\mathrm{DF}^{*}$ & $\mathrm{~F}$ value & $\mathrm{P}_{\mathrm{r}}>\mathrm{F}$ \\
\hline Die Size & 1 & 0.55 & 0.4709 \\
Moisture & 2 & 145.45 & $<.0001$ \\
Die size x Moisture & 5 & 158.61 & $<.0001$ \\
\hline
\end{tabular}

The DDGS color $\left(\mathrm{L}^{*}, \mathrm{a}^{*}\right.$ and $\left.\mathrm{b}^{*}\right)$ results are reported in Tables $10,11,12,13,14$ and 15 . The color $\mathrm{L}^{*}$ results indicate that the DDGS became darker than the original DDGS after pelletizing; which is very similar to the results of Rosentrater (2007). For both of the die sizes used, the L* value decreased as the pellet moisture level increased. It was also observed that the color of the DDGS pellets became darker if the die with smaller diameter was used to pelletize the DDGS. The die size and DDGS moisture level were the main factors that affected the $L^{*}$ value. The color $a^{*}$ and color $b^{*}$ results were similar to the $L^{*}$ results. The $a^{*}$ and $b^{*}$ values were all decreased after the pelleting process. For each die, the $a^{*}$ and $b^{*}$ values decreased as the DDGS moisture content increased. 
Table 10. Color L* of DDGS pellets*

\begin{tabular}{|c|c|c|c|c|c|c|c|}
\hline \multicolumn{8}{|c|}{ Color L* } \\
\hline Run & $\begin{array}{l}\text { Die } \\
\text { (in) }\end{array}$ & $\begin{array}{l}\text { DDGS Moisture } \\
\text { level }(\%)\end{array}$ & Replication 1 & Replication 2 & Replication 3 & Mean & $\begin{array}{l}\text { Standard } \\
\text { deviation }\end{array}$ \\
\hline DDGS & & 10 & 56.58 & 55.83 & 56.76 & $56.39 \mathrm{a}$ & 0.8 \\
\hline 1 & & 10 & 35.22 & 37.43 & 35.18 & $35.94 \mathrm{~b}$ & 1.28 \\
\hline 2 & $1 / 8$ & 15 & 30.36 & 31.47 & 30.25 & $30.69 \mathrm{c}$ & 0.67 \\
\hline 3 & & 20 & 26.91 & 29.64 & 26.37 & $26.64 d$ & 0.27 \\
\hline 4 & & 10 & 46.93 & 45.19 & 45.71 & $45.94 \mathrm{e}$ & 0.89 \\
\hline 5 & $3 / 16$ & 15 & 39.09 & 41.22 & 39.07 & $39.79 f$ & 1.23 \\
\hline 6 & & 20 & 32.89 & 32.92 & 38.77 & $34.86 \mathrm{~b}$ & 3.38 \\
\hline
\end{tabular}

* Different letters after means in each level of the color L* indicates significant difference at $\alpha=0.05$

Table 11. ANOVA of Color L* of DDGS pellets*

\begin{tabular}{llll}
\hline Factor & $\mathrm{DF}^{*}$ & $\mathrm{~F}$ value & $\mathrm{P}_{\mathrm{r}}>\mathrm{F}$ \\
\hline Die Size & 1 & 17.18 & 0.0008 \\
Moisture & 2 & 5.76 & 0.0139 \\
Die size x Moisture & 5 & 51.73 & $<.0001$ \\
\hline
\end{tabular}

*Degrees of freedom

Table 12. Color a* of DDGS pellets*

\begin{tabular}{llllllll}
\hline \multicolumn{2}{l}{ Color a* $^{*}$} & \multicolumn{7}{l}{ Run } & $\begin{array}{l}\text { Die } \\
\text { (in) }\end{array}$ & $\begin{array}{l}\text { DDGS Moisture } \\
\text { level(\%) }\end{array}$ & Replication 1 & Replication 2 & Replication 3 & Mean & $\begin{array}{l}\text { Standard } \\
\text { deviation }\end{array}$ \\
\hline DDGS & 10 & 12.14 & 12.36 & 11.98 & $12.16 \mathrm{a}$ & 0.2 \\
1 & & 10 & 9.33 & 9.56 & 10.32 & $9.74 \mathrm{~b}$ & 0.52 \\
2 & $1 / 8$ & 15 & 8.72 & 8.77 & 8.61 & $8.70 \mathrm{c}$ & 0.08 \\
3 & & 20 & 7.92 & 7.83 & 7.47 & $7.74 \mathrm{~d}$ & 0.23 \\
4 & & 10 & 11.22 & 11.44 & 11.29 & $11.31 \mathrm{a}$ & 0.11 \\
5 & $3 / 16$ & 15 & 10.25 & 10.14 & 10.24 & $10.21 \mathrm{e}$ & 0.06 \\
6 & & 20 & 9.31 & 9.14 & 9.42 & $9.29 \mathrm{f}$ & 0.14 \\
\hline
\end{tabular}

* Different letters after means in each level of the color a* indicates significant difference at $\alpha=0.05$

Table 13. ANOVA of Color a* of DDGS pellets*

*Degrees of freedom

\begin{tabular}{llll}
\hline Factor & $\mathrm{DF}^{*}$ & $\mathrm{~F}$ value & $\mathrm{P}_{\mathrm{r}}>\mathrm{F}$ \\
\hline Die Size & 1 & 13.35 & 0.0021 \\
Moisture & 2 & 7.93 & 0.0045 \\
Die size x Moisture & 5 & 74.75 & $<.0001$ \\
\hline
\end{tabular}

Table 14. Color $\mathrm{b}^{*}$ of DDGS pellets*

\begin{tabular}{llllllll}
\hline \multicolumn{2}{l}{ Color $\mathrm{b}^{*}$} & & & & & \\
\hline Run & $\begin{array}{l}\text { Die } \\
\text { (in) }\end{array}$ & $\begin{array}{l}\text { Moisture } \\
\text { level }(\%)\end{array}$ & Replication 1 & Replication 2 & Replication 3 & Mean & $\begin{array}{l}\text { Standard } \\
\text { deviation }\end{array}$ \\
\hline DDGS & 10 & 22.3 & 23.1 & 22.5 & $22.6 \mathrm{a}$ & 0.4 \\
1 & & 10 & 17.17 & 15.76 & 15.29 & $16.07 \mathrm{~b}$ & 0.97 \\
2 & $1 / 8$ & 15 & 13.82 & 14.86 & 13.93 & $14.23 \mathrm{c}$ & 0.57 \\
3 & & 20 & 13.26 & 14.17 & 13.57 & $13.67 \mathrm{c}$ & 0.46 \\
4 & & 10 & 23.33 & 21.42 & 22.83 & $22.52 \mathrm{~d}$ & 0.99 \\
5 & $3 / 16$ & 15 & 19.86 & 19.82 & 19.41 & $19.69 \mathrm{e}$ & 0.24 \\
6 & & 20 & 17.84 & 17.34 & 17.68 & $17.62 \mathrm{f}$ & 0.25 \\
\hline
\end{tabular}

* Different letters after means in each level of the color $b^{*}$ indicates significant difference at $\alpha=0.05$ 
Table 15. ANOVA of Color $b^{*}$ of DDGS pellets*

\begin{tabular}{llll}
\hline Factor & $\mathrm{DF}^{*}$ & $\mathrm{~F}$ value & $\mathrm{P}_{\mathrm{r}}>\mathrm{F}$ \\
\hline Die Size & 1 & 39.51 & $<.0001$ \\
Moisture & 2 & 2.27 & 0.1381 \\
Die size x Moisture & 5 & 79.38 & $<.0001$ \\
\hline
\end{tabular}

*Degrees of freedom

\section{Conclusions}

This present research study was carried out to understand the physical properties of pelleted DDGS. The die size and DDGS moisture content had effects on the final pellet physical qualities. As expected, adding water can result in a more durable pellet. For the two dies used, that with the larger die diameter resulted in pellet durability which was lower than the other die. By using a pellet mill, the DDGS bulk density can be increased and the DDGS flowability can be improved. In further studies, the processing temperature should be considered as a major variable as should moisture content during the pelleting process. Additionally, the impact of preconditioning should be examined.

\section{References}

ASAE. (2012). S269.5: Densified Products for Bulk Handling - Definitions and Method. St. Joseph, MI: ASAE.

Carr, R. L., Jr. (1965). Evaluating flow properties of solids. Chemical Engineering, 74(2), 163-168. https://doi.org/10.1001/archopht.1965.00970040165007

Fasina, O. O., \& Sokhansanj, S. (1993). Effect of moisture-content on bulk handling properties of alfalfa pellets. Canadian Agricultural Engineering, 35(4), 269-273.

Tumuluru, J. S., Tabil, L., Opoku, A., Mosqueda, M. R., \& Fadeyi, O. (2010). Effect of process variables on the quality characteristics of pelleted wheat distiller's dried grains with solubles. Biosystems Engineering, 105(4), 466-475. https://doi.org/10.1016/j.biosystemseng.2010.01.005

Kannadhason, S. M. (2009). Effects of ingredients and extrusion on aquafeeds containing DDGS and tapioca starch. Journal of Aquaculture Feed Science and Nutrition, 1(1), 6-21.

Liu, K., \& Rosentrater, K. A. (2011). Distillers Grains: Production, Properties, and Utilization. AOCS Publishing.

RFA. (2008). Ethanol industry outlook 2007. Retrieved from http://www.ethanolrfa.org/industry/locations

RFA. (2014). Ethanol industry outlook 2014. Retrieved from http://www.ethanolrfa.org/pages/annual-industry-outlook

Rosentrater, K. A., \& Kongar, E. (2009). Modeling the effects of pelleting on the logistics of distiller grains shipping. Bioresource Technology, 100(24), 6550-6558. https://doi.org/10.1016/j.biortech.2009.07.051

Rosentrater, K. A. (2005). Strategic methodology for advancing food manufacturing waste management paradigms. International Journal of Environmentally Conscious Design and Manufacturing, 5583, 1-13. https://doi.org/10.1117/12.569989

Rosentrater, K. A. (2006a). Some physical properties of distillers dried grains with soluble (DDGS). Applied Engineering in Agriculture, 22(4), 589-595. https://doi.org/10.13031/2013.21212

Rosentrater, K. A. (2006b). Understanding distillers dried grain storage, handling, and flowability challenges. Distillers Grains Quarterly, 18-21.

Rosentrater, K. A. (2007). Can you really pellet distiller's grains? Distiller Grains Quarterly, 3(3), 16-21.

Shreve, B., Thiex, N., \& Wolf, M. (2006). National Forage Testing Association Reference Method: Dry Matter by Oven Drying for 3 Hours at $105^{\circ} \mathrm{C}$. NFTA Reference Methods. National Forage Testing Association, Omaha, NB. Retrieved from www.foragetesting.org

Woodcock, C. R., \& Mason, J. S. (1987). Bulk Solids Handling: An Introduction to the Practice and Technology. New York, NY: Chapman and Hall.

\section{Copyrights}

Copyright for this article is retained by the author(s), with first publication rights granted to the journal.

This is an open-access article distributed under the terms and conditions of the Creative Commons Attribution license (http://creativecommons.org/licenses/by/4.0/). 